\title{
Escaping from the State? Historical Paths to Public and Private Insurance ${ }^{1}$
}

\section{Robin Pearson}

\section{Introduction}

The history of insurance has been characterised, more than for most industries and services, by a wide range of organisational forms, including obligatory and voluntary public mutual institutions; private mutual associations; public and private stock corporations - some with monopoly powers; large unincorporated stock companies; small unincorporated private partnerships; and syndicates of individual underwriters managed in some places (such as Lloyd's) by brokers. ${ }^{2}$

The reasons for this plethora of vehicles remain unclear, as does its impact of on the global development of insurance. It is likely that there were many country specific factors at work that determined the balance of public and private forms of insurance in any one place over time. It may also be possible, however, to identify generic political, economic and cultural factors, common to several markets, which explain why public forms of insurance were more prominent in some economies than in others.

This article examines the potency of path dependent effects in determining the historical distribution of public and private forms of insurance in a range of developed and developing economies. The path dependency literature has expanded enormously

1 Earlier versions of this paper were presented at the X Congress of the Spanish Economic History Association (AEHE) conference in Carmona, and at the XVII World Economic History Congress in Kyoto. I thank the participants for their useful comments, and also the editor and three anonymous reviewers for Enterprise and Society whose advice and suggestions have greatly improved this article.

2 For recent historical approaches to this topic, see Zanjani, "Regulation"; Pearson and Yoneyama, Corporate Forms. The theoretical and economic literature is much larger. Examples include Hansmann, "Organisation"; Hansmann, Ownership; Smith and Stutzer, "Theory of Mutual Formation". 
since its original focus on the persistence of inefficient technologies. ${ }^{3}$ A variety of models, emphasising institutional, locational and other 'fundamentals' as well as economic determinants of path dependence, have been applied, for instance, to the evolution of business strategies, the size of cities, human capital accumulation in Brazil and water rights in the American West, to name some examples. ${ }^{4}$ Curiously, path dependency theory appears to have been seldom applied to financial service industries or used to explain the development of organizational forms. ${ }^{5}$ To this extent, this article makes a novel contribution to the literature on path dependency, although its main purpose is to understand the diversity of organizational forms that have characterised the business of insurance throughout its history.

In their critique of technological path dependence, Liebowitz and Margolis usefully identified three types. ${ }^{6}$ First-degree path dependence is a simple assertion of inter-temporal effects, where technological choices are sensitive to initial conditions but there is no implied inefficiency of outcomes. In second-degree path dependence efficient decisions may not always turn out to be so in retrospect but the inefficiency is not known at the outset. Third-degree path dependence describes a dynamic market failure that is brought about by the persistence of certain inefficient choices, where the initial errors in those choices were avoidable. The argument presented below conforms most closely to the first-degree model, the weakest form of the three. Our

3 The seminal article was by David, "Clio". See also Arthur, Increasing Returns.

$4 \quad$ Sydow et al., "Organizational Path Dependence"; Bleakley and Lin, "History"; De Souza, "Immigration"; Libecap, "Institutional Path Dependence".

$5 \quad$ In a JSTOR survey that I conducted of several hundred articles with path dependence in the title or as keywords, only one explicitly applied the concept to explain the persistence of organisational forms, viz. van Driel and Devos, "Path Dependence in Ports".

$6 \quad$ Liebowitz and Margolis, "Path Dependence". 
survey of a large number of national insurance markets from the eighteenth to the twentieth centuries points to the primary importance of the state and different political cultures in determining the persistence of certain organizational forms in national insurance markets and in ensuring the continuation of the organisational diversity noted above. Our argument, however, makes no claim that state actions locked in inefficient organisational forms and resulted in market failure, the strongest version of path dependence theory.

Our focus, therefore, is on the state and the historical development of the insurance industry in a wide range of economies. The following section examines the history of the state as an exogenous force shaping insurance markets. The subsequent three sections examine the state as a participant in those markets in the early modern and modern eras, including its role in social insurance and nationalisation. The conclusion identifies the determinants of organizational forms in insurance, and also discusses the impact of different insurance vehicles on market development, thus touching on the efficiency question. The relative costs and benefits of public and private forms of insurance, however, amount to a huge topic for a future international comparative study, and much of the detailed research for many countries on questions such as market distortions and crowding out remains to be done.

\section{The state as gatekeeper, regulator and facilitator.}

In relation to insurance markets, the state has had four principle historic functions: those of gatekeeper, regulator, facilitator and participant. Through the exercise of these functions, states have, at different times and in different places, constricted, created, grown and distorted markets both to the cost and benefit of consumers and 
insurers. The sections below focus on the state's role as a participant in insurance and the forms in which this occurred. This section outlines the early history of the other three functions.

Since the fifteenth century European states have acted as gatekeepers to the insurance market, prohibiting or authorising certain types of insurance, certain types of organisation and other vehicles for insurance provision such as agents, and, in places, the volume of insurance supplied by private individuals and organisations. The clearest example of prohibitory gatekeeping was the ban on forms of life insurance that were regarded as wagers in both Catholic and Protestant states between the fifteenth and eighteenth centuries. Thus, Venice banned wagers on the pope's life in 1419 , in Spain all forms of life insurance were suppressed by the Ordinances of Barcelona in 1435, and Genoa prohibited insurance on kings, princes, bishops, popes, cardinals and other objects of insurance gambling in 1467,1475 and $1494 .^{7}$ Other examples of state proscriptions included the parliamentary ban on marine reinsurance in England in 1746. This statute (19 Geo.II c.37) was enacted because of concerns about the lack of insurable interest in many insurance policies and the opportunity presented by reinsurance contracts for the fraudulent concealment of information by direct insurers. ${ }^{8}$ Such prohibitions were imposed not just by monarchical regimes but also by republican governments. The first life and fire insurance corporations in France, licensed by royal authority, were banned by the National Convention in 1793 . In many US states in the nineteenth century buying reinsurance from companies not authorized to do business in the state was prohibited. ${ }^{9}$

$7 \quad$ Roover, "Marine Insurance".

8 The reinsurance ban was not repealed until 1864. Raynes, British Insurance, $167-8$

9 See, for example, the list in Hayden's Cyclopedia, 1906-7 (New York, 1907). 
The European prohibitions on life insurance derived from religious-ethical anxieties about the use of insurance as wagers and the negative social and political effects on ancien regime populations. In early modern England, by contrast, the lives of ship passengers continued to be insured, albeit in small numbers, in marine insurance policies that came to be governed by common law. The latter, unlike the continental Law Merchant, did not draw on Roman legal precepts that regarded life insurance as unethical because it was a form of trading in lives. ${ }^{10}$ By the eighteenth century, as the importance of religious doctrines in political culture began to wane, and long before law courts drew a formal distinction between illegal wagers and legal life insurance based on an insurable interest, life insurance in England grew via small private mutual schemes such as 'mortuary tontines' - at least 60 were launched between 1696 and 1721 - as well as via larger and more permanent organisations such as the mutual Amicable Society of 1705, and the two London stock corporations of 1720. ${ }^{11}$ Thus differences in political cultures and legal traditions helped determine variations between European states in the treatment of life insurance, and this in turn ensured a continuing diversity in the forms by which it was delivered.

Other things being equal, governments have the power to limit moral hazard more thoroughly and cheaply than private insurers can through market operations. Rather than prohibiting insurance outright, some regimes employed their licensing procedures to control supply and demand in an attempt to eradicate over-insurance and what they perceived to be the attendant moral hazard and social evils. This

\footnotetext{
10 Clark, Betting on Lives, 19. By contrast, the Spanish and Antwerp marine insurance ordinances made no mention of insuring lives at sea. Kepler, "London Marine Insurance", 51. On the relative ineffectiveness of the Law Merchant applied to marine insurance cases in England, see Jones, "Elizabethan Marine Insurance". 11 Clark, Betting on Lives, 71-99. The distinction between wagers and life insurance was enshrined in the Gambling Act of 1774.
} 
practice was especially prevalent in northern and central Europe during the eighteenth and nineteenth centuries, where political cultures were generally characterized by autocratic governments, powerful bureaucracies, and police forces committed to an array of monitorial and social-disciplinary actions. ${ }^{12}$ This was manifested in the form of 'preventative controls' on fire insurance contracts and restrictions on who was permitted to insure, as well as tightly controlling the issue of licenses to companies and their agents. The Duchy of Magdeburg, for example, required farm labourers and other workers to subject any property they wished to insure to an exact valuation, in order to prevent 'dissolute and immoral people' (liderliche Leute) from over-insuring. Regulations to reduce the moral hazard associated with over-insurance and excessive claims payments continued in Germany well into the nineteenth century, underpinned by the belief of state officials that not all citizens were 'mature' enough for private insurance. A Saxon government order of 1828 required policyholders to obtain the approval of the local police captain (Amtshauptmann), before they could co-insure their property in more than one company. In Württemberg a law of 1852 required policyholders to obtain a certificate of valuation from the local council $(\text { Gemeinderat })^{13}$

Another device to regulate supply was the requirement in some states for companies to show that their business met a public 'need'. In Prussia, for example, under a law of 1837 , new companies wishing to obtain licenses from the Ministry of Interior, or licensed companies wishing to appoint additional agents in cities, had to provide proof that there was a 'demand' (Bedürfnis) for their services. This proof took

12 The literature is large, but see, for example, Koselleck, Preussen; Lüdtke, Police and the State.

13 Gesellschaft, Deutsche Feuerversicherungswesen, volume 2, 219. 
the form of a testimony from the local town or county administration that the demand existed. It does not seem to have been based on any empirical evidence or scientific investigation of data. Indeed, critics pointed out that many existing insurance companies in small towns appointed the local mayors and councillors as their agents, who therefore had a vested interest in preventing the admission of new competitors. ${ }^{14}$ The requirement was abolished in Prussia in 1859, but survived longer in other states such as Austria and Baden.

Increasingly during the nineteenth and early twentieth centuries many governments, usually for ideological reasons or acting under external political pressure, extended their gatekeeping functions to impose discriminatory fiscal and regulatory burdens on foreign insurers in an effort to deter entry and encourage exit. Examples include the higher tax rates charged on foreign companies compared to their domestic competitors in Sweden in 1857, Belgium in 1907, and several American states such as Pennsylvania (1856), Massachusetts (1862), Missouri (1866) and Kansas (1899). ${ }^{15}$ Deposit, policy, and reporting requirements could also be made taxing to foreign companies applying to enter a market. Legislation in Bulgaria in 1898, for example, required all foreign insurers to make deposits in government securities. ${ }^{16}$ Some American states required foreign companies to deposit cash in each location in the state where they had agents. Thus, in Ohio in 1858 the deposits required ranged from $\$ 50,000$ in Cincinnati to $\$ 10,000$ or $\$ 20,000$ in other cities. ${ }^{17}$

$14 \quad$ Rundschau der Versicherungen 13 (1863): 368-72.

15 For Sweden, see Lönnborg, Internationalisierung, 72. For Belgium, see Assecuranz Jahrbuch 14 (1893) 431; ibid. 29 (1908) 283. For the US, see First Annual Report of Insurance Commissioner of Pennsylvania (1873); Western Insurance Review III (1869-70), 382; ibid. I (1867-8), 310-11.

16 Assecuranz Jahrbuch 20 (1899): 436-7.

$17 \quad$ United States Insurance Gazette 8 (1858-9): 379. 
In the past states have also frequently restricted or directed the supply of insurance by issuing monopoly privileges to for-profit private groups, usually in return for some revenue benefit. With some of these ventures the lines between state monopoly and private monopoly authorised by the state were particularly blurred, especially where compulsion was involved. This was a favourite device of ancien regime governments in Europe. One example is the monopoly on corporate marine insurance issued to two groups of investors in London in 1720, who formed the Royal Exchange Assurance and London Assurance companies in return for 'loans' of $£ 300,000$ each to the Crown. The effect was to drive business towards underwriters at Lloyd's, who were not subject to the restriction on corporate underwriting. The monopoly was finally repealed in 1824 , but by then over 95 per cent of marine insurance in Britain was underwritten at Lloyd's. ${ }^{18}$ This is a good example of how state-authorised private monopolies could distort a market and skew it in one direction at the expense of alternative forms of supplier. Other examples occurred in Russia. Having rejected the idea of a public insurance institution, in 1827 the Tsarist state issued an exclusive monopoly charter for the First Russian Fire Insurance Company of St Petersburg to insure property in the residence towns, Odessa and the Baltic provinces. In 1835 a similar charter was issued to the Second Russian Company for other gouvernements. These monopoly privileges were repealed in 1847, but important restrictions continued. Thereafter, Russians could only insure with foreign companies if they had already been refused insurance by the Russian companies. ${ }^{19}$

The state could also facilitate the growth of insurance by reducing risk and by collecting and publishing information on hazards and others events. With its national 
resources, it could do this on a scale and frequency that private companies could not, until the latter began to collaborate more effectively towards the end of the nineteenth century when faced with a new range of technologies. ${ }^{20}$ Early examples of state intervention in this area include data on deaths in English towns collected by local churchwardens in parish registers. In the early nineteenth century, most English life insurance companies based their premium rates on the mortality tables constructed from the registers of Northampton and Carlisle by Richard Price in 1781 and Joshua Milne in 1815 respectively. The actuarially unfair prices produced by these tables which suggested a much higher level of mortality than contemporary life insurers were experiencing among their policyholders - probably acted as a stimulus to investment in new life insurance companies. There were only six such companies in England in 1800 but over 150 by 1850 . Legislation to combat overcrowding and poor sanitation in urban areas, together with improvements to public health services, by reducing the frequency and virulence of epidemics and lowering average mortality, were other ways in which the state contributed to the growth of cheaper life insurance. ${ }^{21}$ Some $£ 290 \mathrm{~m}$ was insured on lives in Britain in 1870 , up from $£ 12 \mathrm{~m}$ in $1800 .{ }^{22}$

20 The most striking manifestations of this collaboration were the risk inspection bureaus established by various fire underwriters' associations in US cities and regions in the $1880 \mathrm{~s}$, which gave rise to the famous Underwriters' Laboratories (UL) in 1894. By 1922 UL were distributing 500m safety approval labels on industrial and consumer products per year. Tebeau, Eating Smoke, 283-4. I am grateful to an anonymous reviewer for pointing to this development.

21 In Victorian Britain the public health movement began with the report of the parliamentary committee on the health of towns (1840) and Edwin Chadwick's Report on the Sanitary Condition of the Labouring Population of Great Britain (1843). These were soon followed by legislation such as the Nuisances Removal Act (1846), the Metropolitan Commission of Sewers Act (1848) and the Public Health Act (1848).

22 Trebilcock, Phoenix Assurance, volume 1, 578-9, 603-9; Supple, Royal Exchange, 111-12, 131-2. 
Public authorities at local and national level, with their powers of enforcement and tax-raising capacity, were usually better equipped than private insurers to prevent or mitigate the number and intensity of physical hazards such as fire, flood, windstorm and earthquake, as well as to counter the dangers of new technologies. From the late middle ages, the building codes of numerous English towns attempted to reduce the fire hazards caused by shoddy construction and inflammable materials. ${ }^{23}$ In many places fire-fighting was organised, albeit often inefficiently, by local authorities, and parish fire brigades supplemented the private brigades of the fire insurance companies.

States could also help private insurers cope with the risks involved in insuring against the hazards brought by new technologies. The regulation of road traffic is one area in which the state played a major role in facilitating the growth of an insurance market in many countries. ${ }^{24}$ Another example is engineering and machinery insurance. The boiler explosions acts passed by the British parliament in 1882 and 1890 greatly added to the functions already carried out by the specialist boiler insurance companies that had emerged since the $1850 \mathrm{~s}$. The legislation made provision for the investigation of all commercial boiler explosions by engineers appointed by the Board of Trade. Further provision for the regular inspection of boilers was made by the Factory and Workshop acts of 1901, 1911 and 1920, and this principle of official safety inspection was extended in the early twentieth century to all classes of powered machinery, helping engineering insurance to develop as a specialist class of underwriting. ${ }^{25}$

23 Pearson, Insuring the Industrial Revolution, 60-1, 83-4.

24 Westall, "Invisible Hand"; Mohun, Risk, 175-9, 186-8.

25 Raynes, British Insurance, 291-2. 
In sum, these three exogenous roles of the state, as gatekeeper, regulator and facilitator, in shaping the business and legal environment for different organizational forms in insurance, arguably created path dependent effects, in the sense that state actions, and national political cultures more generally, helped particular business forms persist over time in different economies, and ensured the continuing diversity, rather than the organizational convergence, of the industry.

\section{The state as participant: public insurance and state ownership in the early modern period}

Public authorities have also participated, directly or indirectly, in insurance markets. When entering these markets as actors and not simply regulators, states have certain advantages over private insurers. As Robert Wright has noted, governments have powers that private insurers do not, including the ability to limit adverse selection by compelling individuals and businesses to enrol in a public insurance program and forcing them to pay premiums and taxes. ${ }^{26}$ Governments have longer time horizons that enable them to withstand economic downturns more efficiently than private companies, and they often have deeper pockets to provide emergency relief, victim compensation and recovery support in the wake of large disaster events. There are disadvantages too, which have been widely commented upon. Public insurance can be inefficient, it can distort markets and it can generate serious asymmetric information and adverse selection problems. These issues are examined below. First, however, this section outlines the different forms that have been taken by state actors in insurance markets.

26 Wright, "Insuring America". 
In early modern Europe, while private underwriters and brokers continued to operate in many ports, some states moved to found monopoly institutions for marine insurance, such as those in Genoa and Copenhagen in 1742 and 1746 respectively. ${ }^{27}$ In 1751 the Kingdom of Naples created the Real Compagnia di Assicurazioni Maritime. All merchant ships operating out of Naples were required to insure in the company, though many Neapolitans still preferred to insure in London where premiums were lower. Once the Real Compagnia was abolished in 1802, the Neapolitan market was returned to private operators, but instead of being confined to individual underwriters as before, a number of new marine insurance companies began to appear, beginning with the Societa Napoletana di Assicurazioni Maritime in 1811. By the late 1850 s several dozen companies - ranging from small partnerships to large joint stocks - had been founded in Naples, Messina and Sorrento, suggesting that a pent-up supply of marine insurance capacity had been suppressed by the monopoly of the royal company. ${ }^{28}$ Clearly the development of marine insurance in Genoa, Naples and Copenhagen was skewed by these monopoly institutions, although given the current limited state of research, it is difficult to know whether in their absence private corporate forms would have emerged earlier than they did. In the case of Trieste, where there was no state monopoly, several private stock companies formed for marine insurance during the late eighteenth century, but most failed during the Napoleonic wars when Trieste lost business to more price competitive centres in Hamburg, Amsterdam and London. ${ }^{29}$

\footnotetext{
27 Rohrbach, "Von den Anfängen," 179.

28 Sirago and Avallone, "Risk of the Sea".

29 In part this was due to the lack of convoy facilities available to Austrian ships trading out of the port. Rohrbach, "Von den Anfängen," 184-5.
} 
On the whole, the evidence from early modern Europe suggests that direct participation by the state in marine insurance had limited success. One probable reason was that marine risks were non-standardised, and therefore relatively costly to handle for large corporations with high overheads. It was difficult to construct standard tariff schedules on an actuarial basis to price such risks. Second, the international regulation of marine underwriting at an early date reduced transaction costs for the individual underwriter and increased the confidence of shippers seeking insurance. ${ }^{30}$ Third, as Kingston has argued, well organised systems of individual underwriting such as Lloyd's of London could deliver information advantages over their corporate rivals. ${ }^{31}$ Where markets of individual underwriters were less developed, where there were doubts about the security of the contracts issued, and where the political, legal and economic environment was conducive to the formation of joint stock enterprises, as in the United States around 1800, private corporations could prevail, but there were no obvious competitive advantages for state corporations in marine insurance, at least in peacetime. ${ }^{32}$ Some states, however, retained a direct involvement in marine insurance for political reasons. During the 1870s in China, for instance, several public-private insurance ventures appeared, beginning with the China Merchants Steam Navigation Company, with the Manchu government as a shareholder. It was the first example of the Chinese state moving into the insurance

30 Ordinances issued at Barcelona between 1435 and 1484 placed maritime insurance under the Consulat de Mar, which formed the basis for international commercial law in the Mediterranean. Further ordinances were passed in Italy, Spain, Flanders, and England during the sixteenth and early seventeenth centuries, and chambers of insurance were set up in several ports to prevent fraud, reduce the costs of disputes, and establish the principle of full disclosure between insurers and the insured. See Leonard, Marine Insurance.

31 Kingston, "Marine Insurance in Britain and America".

32 Kingston, "Marine Insurance in Philadelphia". 
business as part of a wider nationalist strategy to bolster the economy, and particularly Chinese shipping, against foreign competition. The China Merchants Steam Navigation Company and its related companies proved successful and opened overseas branches in Singapore, Philippines and San Francisco. They closed after the crash of $1929 .^{33}$

In early modern Europe there is much greater evidence of state participation and success in fire insurance than marine insurance. This was part of a growing mercantilist interest in utilising government powers to improve the security of private property and incomes, not least in response to the huge revenue needs of the fiscal-military state. ${ }^{34}$ Public fire insurance derived from the medieval tradition of briefs and compulsory collections for victims of fires. Such collections, for example, took place at county and parish levels in Denmark, Germany, England and Sweden. From the late seventeenth century, this traditional system of public post hoc relief for losses by fire, was supplemented by various municipal and state institutions for the insurance of buildings, in some places accompanied by compulsion. The first successful public fire insurance institution was the Hamburger Feuerkasse of 1676 which originated in local 'fire contracts', written agreements between groups of about 100 owners of property within the town walls by which, in return for a fixed subscription, victims of fire would receive compensation towards repairing or rebuilding their property. ${ }^{35}$ The contracts were private arrangements, but from 1620 they were required to be confirmed by the town senate, thus lending them a degree of official recognition. By the 1670s there were some 46 'fire contracts' in Hamburg.

\footnotetext{
33 Kang, "Assurances Moderne".

34 Brewer, Sinews of Power; Schulze, "The Tax State,"

35 The following is based on Büchner, "Hamburger Feuerkasse". See also Zwierlein, Der gezähmte Prometheus, 223-42.
} 
Their small scale and the difficulty of spreading risk in a confined area led the senate to combine all the contracts into one new insurance fund, the Feuerkasse, to be administered by council officials. There was no compulsion on existing householders to join the fund - compulsion was first introduced in 1817 - but whoever built a new house or bought or inherited a house was required to join. Losses were adjusted by deputies of the Feuerkasse, assisted by selected craftsmen. In the event that the fund proved insufficient to cover payments, members were liable for further calls at fixed rates proportionate to the sums they had insured. The fund was also used to pay the medical bills of citizens injured fighting fires or a lifetime annuity to those rendered permanently disabled, as well as the burial costs of the victims of fires. The institution thus combined elements of a mutual association with those of a state-administered public welfare body.

The Hamburg Feuerkasse provided a model for mercantilist regimes elsewhere to copy. Public buildings insurance societies were formed across much of Germany during the late seventeenth and eighteenth centuries. ${ }^{36}$ They were also formed in Denmark in 1731, in Switzerland, where cantonal insurance began in 1782, and in Sweden, where the government organised a General Fire Insurance Fund in 1782. Most public societies were local or regional in scope, and, as extensions of state bureaucracy and revenue systems, managed by civil servants, they were characteristic of the political cultures into which they were born. The 'Fire Society for the Towns in the Duchy of Cleve and the County of Mark', for example, was managed by an official commission appointed by the province, while the Westphalian state tax German-speaking territories between 1676 and 1817. Zwierlein, Der gezähmte Prometheus, appendix II, 370-2. 
commissioner, appointed by the King, decided upon the contribution quota for each town. Here and in the other public insurance societies in Prussia soldiers were on guard as claimants appeared personally before the town magistrates to receive their payouts. There was no corporate identity and often no specific building - they were administered from a desk in a government building as one of several public funds, including funds for schools, churches and the poor. Insurance was generally issued on a non-actuarial basis. Policyholders were usually charged flat fees for all types of property, and the fees were paid like any other tax (a crude risk classification was first introduced by the Hamburger Feuerkasse in 1753, and only later by other societies). Public insurance societies were non-profit organisations. Their primary purpose was to pay for the rebuilding of property damaged by fire, while any surplus left was normally used to supplement other forms of welfare expenditure. There was often a compulsory rebuilding clause inserted into members' contracts, and payments were usually made on the basis of historic rather than rebuilding cost. ${ }^{37}$ Yet for all their limitations from a modern perspective, the public societies appear to have been remarkably successful, insuring between 50 and 75 per cent of property in some parts of northern Europe. ${ }^{38}$

With urban growth the public societies increasingly faced a problem of changing cost structures. Where they insisted on a level of self-insurance, property owners turned to private companies to fill the gap. From 1840 under the growing influence of liberal ideologies, authorities began to permit private insurers to compete freely with state institutions in three Prussian provinces, Rhineland, Westphalia and

37 Büchner, "Hamburger Feuerkasse", 26.

38 Zwierlein, Der gezähmte Prometheus, 297-8. 
Poznan. ${ }^{39}$ Traditional suspicions of private insurance lingered, but states increasingly placed limits on the extent of their participation in fire insurance. A common weakness was the inability of public societies to accumulate sufficient funds to cope with major fire disasters in urban areas. This was true, for example, of the Swedish General Fire Insurance Fund of 1782, which, after several large town fires, ran out of money to meet claims. Its managers were also reluctant to insure poorer risks housing not built with fire resistant materials - which led to conflict between different interest groups in the Fund. By 1828 the Fund had split into three separate organisations, one insuring only rural property, one insuring urban property, and a third formed by policyholders themselves exclusively for the southernmost province of Sweden. ${ }^{40}$

Private companies insuring contents against fire were tolerated by ancien regimes, not only because of the complexities of underwriting non-standard risks that were increasingly subject to technological change, but also because the policyholders were mostly wealthier merchants and property owners who were regarded as literate and numerate enough to understand what they were buying. As private insurance companies began to carve out a market for the insurance of moveable goods, nineteenth-century states responded by removing the monopoly of public societies for buildings insurance, thus forcing them to compete with private stock and mutual companies in a more open market. At the same time, efforts were made, for instance in Prussia during the 1820 s and 1830 s, to combine the smaller societies into larger regional bodies in order to improve their competitiveness. ${ }^{41}$ In several countries this

39 Borscheid, "Insurance Industry in Germany," 49.

40 Larsson and Lönnborg, "Insurance Companies in Sweden," 199.

41 Borscheid, Feuersozietäten. 
seems to have worked, for public fire insurance societies managed to sustain their share of the market. In Denmark in 1827, for example, state insurance on buildings amounted to $£ 18.1 \mathrm{~m}$, compared to $£ 19.1 \mathrm{~m}$ insured by the largest private society, the Brandforsikkring for Huse og Gaarde. ${ }^{42}$ In Germany public societies accounted for 36 per cent of all sums insured against fire in 1879 , and still 34 per cent in $1910 .{ }^{43}$ Around two thirds of this derived from compulsory buildings insurance, the rest from voluntary buildings and contents policies. ${ }^{44}$ There is little question that public insurance crowded out the supply of private fire insurance in such markets over a long period. It also contributed to the fragmentation of markets, and perhaps increased consumer choice and kept prices down by reducing the power of the tariff associations of private companies, although this requires confirmation by further research. In sum, different kinds of direct participation by early modern states in national insurance markets, and the political cultures that facilitated such participations, shaped the organizational structure of these markets in ways that proved remarkably persistent through time.

\section{The state as participant: social insurance in the modern era}

Three basic types of social insurance existed from the late nineteenth century: voluntary and compulsory employment-based social insurance, largely delivered by private for-profit providers with some state oversight; and compulsory not-for-profit universal integrated social security and health insurance systems provided and managed by the state. In their different ways and at different times these delivered

\footnotetext{
42 Brown, "Fire Insurance".

43 Calculated, respectively, from Assecuranz Jahrbuch 10 (1889): 278; ibid. 33 (1912): 208.

44 The ratio relates to 1877 and is calculated from data in Rundschau der Versicherungen 29 (1879): 255-6.
} 
insurance against sickness, workplace accidents, unemployment and old age for ever larger numbers of people. The voluntary accident insurance schemes provided by private companies were stimulated by the first generation of employers' liability legislation in Europe. The Imperial German liability law of 1871, for example, made employers in sectors such as mining and railroads liable to their employees in the event of workplace injuries, though insurance was not obligatory. Any compensation paid by an employer's insurance company was set against the compensation granted by a court, on the assumption that the insurance would cover only part of the employer's legal liability. This greatly increased the demand in Germany for private accident insurance. The belief was that injured workers or their relatives would give up costly litigation against employers once compensated by such insurance payments. ${ }^{45}$ Similarly in the UK the Employers' Liability Act of 1880 made employers liable for injuries caused to certain classes of employees by negligence in the workplace. The effect of this legislation was to give private providers a much wider field for personal accident insurance. The Workmen's Compensation Acts of 1897 and 1906 extended the principle of compensation to new groups of British workers, to accidents not necessarily caused by negligence, and to ill health caused by industrial diseases. This was an example of state intervention intentionally creating a huge new market for private insurance companies without encroaching directly on the operation of the business.

Compulsory-contribution employment-based social insurance first appeared in Germany with Bismarck's national health insurance legislation in 1883, statutory accident insurance in 1884 and state disability and old age insurance for workers in

45 Arps, Auf Sicheren Pfeilern, 65-6; Stadlin, “Actuarial Practice," 44; Guinnane and Streb, "Incentives". 
1889. In the volatile political culture of the Second Reich, Bismarck expressly viewed these new social insurance schemes as devices to wean discontented industrial workers away from Social Democracy and Marxism. ${ }^{46}$ Rising medical costs, together with the limited provision of medical and hospital services, increased incentives to insure against loss of income from sickness, but private health insurance remained beyond the pockets of most German workers. This weak market for private health insurance helps explain the limited resistance to the new legislation. The health insurance scheme of 1883 , for example, comprised a system of sickness funds based either geographically or in particular firms or guilds. Employers were required to provide insurance for all employees earning less than 2000 marks p.a., although those who earned more were allowed to buy into the scheme. Premiums were paid two-thirds by the worker and one-third by the employer. The insured were entitled to free medical and other auxiliary treatment. Benefits also included cash payments up to half of the worker's wage for a given period of sickness or incapacity, after which trade associations covered the cost of any treatment. Doctors were contracted and paid directly by the funds for their services. ${ }^{47}$ The initial legislation applied only to certain categories of industrial worker, covering about ten per cent of the population, but by 1927 coverage had been extended to transport, clerical, farm and forestry workers, domestic servants, government employees, seamen and the unemployed. These statutory schemes helped spread the understanding of insurance through German

\footnotetext{
46 Cf. Bismarck, Dokumente, no. 317 Im Gespräch mit Moritz Busch, 21 Januar 1881; Bebel, Aus meinem Leben, 754-6; Engelberg, Bismarck, 379-416. 47 Arps, Auf Sicheren Pfeilern, 124-6; Winegarden and Murray, "Early Health Insurance".
} 
society. Life insurance premiums in Germany, for instance, increased from $86 \mathrm{~m}$ Marks in the 1880 s to $278 \mathrm{~m}$ Marks in the 1900 s. $^{48}$

The development of a compulsory contribution system in Germany provided a model for many other countries. In Sweden mandatory industrial injury insurance, delivered by private companies, was legislated for in 1901 and 1916. In Austria accident insurance was made mandatory for large industrial firms in $1887 .{ }^{49}$ In the US between 1900 and 1920 three systems co-existed. Monopoly state funds to provide workmen's compensation were set up in some states (Ohio and Washington in 1911, Nevada, Oregon and West Virginia 1913, Wyoming 1915, North Dakota 1919) where insurance and farming interests were weak and unions strong, or where progressives swept into power. Legislation to establish state funds against which private insurers were allowed to compete was passed in a further ten states beginning in Michigan in 1912. Elsewhere experiments in state insurance were rejected. In many American states the debate was whether workmen's compensation insurance should be purchased from a state fund or whether employers should be free to buy from private companies. Unions lobbied hard for state insurance on the grounds that private companies should not profit from the misfortunes of injured workers, and that public insurance could eliminate the overheads and profits of selling private insurance, so that employers' premiums could be reduced and workers' benefits increased. The private companies claimed that the state had no actuarial experience and that only they had the expertise to adjust rates for the different accident rates experienced across industries. In sum, both the varying alignment of narrow interest groups and broader political interests in different states determined the fate of public monopoly

48 Borscheid, "Vertrauensgewinn," 317.

49 Murray and Nilsson, "Accident Risk Compensation". 
legislation and the shape of accident insurance systems in the US during the early twentieth century. ${ }^{50}$

By contrast, in Britain the legislation of 1897 and 1906 failed to establish any public competitor to the private provision of workmen's compensation insurance. Not until a government committee of 1920 was the question of a state fund, operating either as a monopoly or in conjunction with private companies, or a state system of mutual insurance, considered. By this time there were already 65 insurance companies underwriting workmen's compensation business. In addition, about 10,000 employers were organised in mutual associations in the seven industrial groups to which the 1906 act applied, covering perhaps one third of all firms. The business had been profitable but expensive for employers. The committee of 1920 concluded that the existing system could be allowed to continue, but under stricter state supervision, led by a commissioner with powers to grant licences to companies and mutual associations to write workmen's compensation insurance. An act to this effect was passed in 1923. Not until 1945, however, was a comprehensive state system of contributory social insurance adopted, a system that finally superseded the private provision of workmen's compensation insurance. ${ }^{51}$

The statutory health insurance programmes that appeared in Europe before 1914 differed greatly between countries in terms of their coverage, organisation, finance and method of delivering medical care. Health insurance was introduced by statute in Italy, Austria, Sweden, Denmark, Belgium, and France between 1886 and 1898, and then in the UK, Norway and Switzerland between 1909 and 1911. Denmark and Sweden began with voluntary schemes after studying the German model. In 1894

$50 \quad$ Fishback and Kantor, "Durable Experiment".

51 Raynes, British Insurance, 301-15. 
and 1898 Belgium granted legal advantages to private sickness funds that registered with the government and subsidies to those that submitted to state regulation, but not until 1914 was health insurance made compulsory. In France from 1898 friendly societies that provided sickness benefits received government subsidies. Such schemes appear to have accelerated the reduction in European mortality before 1914. 52

In the US state and federal governments fostered the employment-based system of private provision that has remained dominant to the present day. Demand for health insurance increased from the 1930s with advances in medical technology and rising health care costs. At same time, hospitals pushed to have pre-paid plans developed for their services, which became combined under the names Blue Cross and Blue Shield. These plans gained non-profit tax-exempt status, which initially gave them an advantage over commercial competitors. Several states also exempted them from existing insurance regulations and reserve requirements, while insisting that the same premiums be charged for sick members as healthy members. During the 1940s commercial insurers gained ground on the Blues by basing their rates on experience and offering lower premiums to younger workers. In 1942 the War Labor Board allowed firms to attract workers using fringe benefit packages, which also boosted employment-based insurance. Tax subsidies and tax exemptions of employers' health insurance premiums, introduced in 1943 and 1954 respectively, provided further state support to employer-provided health insurance, lowered its relative price, stimulated the growth of group schemes, and encouraged people to buy more comprehensive

\footnotetext{
$52 \quad$ Winegarden and Murray, "Early Health Insurance".
} 
cover. Thomasson has shown that from the 1950s Americans with health insurance spent significantly more on medical care than those who remained uninsured..$^{53}$

In the UK the German model of compulsory contributions ran against the grain of Victorian liberalism and social policy. Arguments against compulsory schemes centered on the alleged need to incentivise the 'respectable poor', and on the opposition of trade unions and friendly societies defending their own benefit funds. The German model did, however, have a major impact on the reforms of 1908 to 1911, when the Liberal government finally introduced compulsory contribution insurance for sickness, invalidity, old age and unemployment. ${ }^{54}$ In 1925 a contributory non-means tested social insurance was introduced in Britain, but membership was compulsory only for employees earning below $£ 250$ p.a.. Not until the National Insurance Act of 1946 was compulsory, unified and universal social insurance introduced in the UK, funded on a pay-as-you-go basis, i.e. by a tax on current expenditure. In 1948 the state pension was underpinned by National Assistance, which retained a means test for supplementary benefits to help the poorest pensioners. The increasingly inadequate basic pension, which lagged in value behind average earnings, resulted in 27 per cent of pensioners claiming the supplementary benefit by $1954 . .^{55}$

Sweden introduced mandatory state pensions in 1913, to be delivered, like Sweden's mandatory industrial injury insurance, by private companies. In the 1950s

53 Thomasson, "From Sickness to Health".

54 The 1908 act established a non-contributory means-tested pension from the age of 70 funded out of general taxation. It proved inadequate. The German model was ruled out, as it had been before. Macnicol, Politics of Retirement, 156-62. The German system of compulsory contributions was finally adopted in the National Insurance Act of 1911. Hennock, British Social Reform; Pearson, "Who Pays for Pensions?"

$55 \quad$ Hannah, Inventing Retirement. 
the Swedish Social Democrats argued for a supplementary pension reform built upon the mandatory scheme, with the state guaranteeing the benefits against inflation, while other parties supported a voluntary system with or without state guarantees. The result of the debate was the supplementary pension reform of 1959 , introduced after the appointment of a Social Democrat minority government. ${ }^{56}$

In the US mandatory pension insurance was finally enacted in 1935, after long resistance by private insurers. The US was the last industrial country in the world to enact a national (federal) scheme to help the elderly. By 1920 mandatory old age insurance had already been established in ten European countries. By contrast, of 21 reports commissioned by US state legislatures by 1929, only one recommended compulsory insurance. It took the exigencies of the Great Depression to compel American legislators to take action. ${ }^{57}$ In Latin America social insurance programs evolved in a piecemeal and stratified fashion, segmented by occupation, with interest groups extracting different levels of concessions from the state. The armed forces, civil servants, professionals and white-collar employees obtained the most generous health care benefits and pensions, while rural workers and workers in non-strategic industries invariably obtained the worst due to their weaker bargaining power. While the latter had the lowest costs and contribution rates, they also experienced lower than average life expectancy and the poorest insurance coverage. ${ }^{58}$ What the above survey clearly shows is that different political and legal regimes, as well as macro-economic conditions such as average purchasing power and levels of development, were the

56 Larsson and Lönnborg, "Insurance Companies in Sweden," 220-1.

57 Weaver, "Political Market".

58 Mesa-Lago, "Social Security in Latin America". 
primary determinants of the type of social insurance systems - public, private, or some blend of the two - that appeared from the late nineteenth century.

\section{The state as participant: nationalisation}

It remains to ask why some modern states nationalised, or partly nationalised, their insurance industries? History suggests three, often interconnected, reasons. First, fiscal-monetary motives sometimes played a part: faced with economic difficulties, some governments sought to gain control of the revenue streams generated by financial services. Second, policies of autarky or economic nationalism, often bound up with right- or left-wing political ideologies, viewed nationalisation as a means to stop the outflow of funds to foreign companies. Third, certain regimes, sometimes socialist or social democratic, sometimes based on religious beliefs, viewed private insurance with hostility on moral or ideological grounds. They regarded nationalisation as a device to counter practices harmful to public welfare, notably the high costs, poor governance and rent seeking that they associated with private insurance organisations.

The latter argument appeared in the debates on insurance nationalisation that took place in Imperial Germany. Bismarck repeatedly accused private insurers of distributing excessive dividends to shareholders to the detriment of their policyholders. On religious-ethical grounds he claimed that profits should not be made out of the misfortune of individuals. On economic grounds he argued that a state institution could deliver insurance more cheaply than private companies, and called for a comprehensive scheme providing all types of insurance on a mutual basis. He received support from conservative agrarian groups, who thought this might help 
bind German workers to the existing social order, and from the influential economist Adolph Wagner, who saw in state insurance an opportunity to engage in social engineering by redistributing premiums from the wealthy to the poor, making those who represented the lowest risks pay the highest premiums. Opposition came from the private companies, from the insurance press, liberal politicians and the Congress of German Economists. In the end, Bismarck's full nationalisation was not carried through. Instead, as noted above, the growth of the private insurance sector in Germany was actually stimulated by the social insurance legislation of the 1880 s and 1890 s. $^{59}$

Other countries that opted to nationalise their insurance industries, or parts thereof, included New Zealand, who established a state life insurance office in 1870. By 1904, this office accounted for nearly half the life insurance sold in New Zealand. Insurance in it was compulsory for civil servants, whose premiums were paid by a deduction from salaries at source. The venture was run on a non-profit basis, but the government did receive an annual revenue from the life office, which was treated for tax purposes like a private corporation. Further state offices for accident and fire insurance were set up in competition with private companies in 1899 and 1903 respectively. ${ }^{60}$

In Italy before the First World War there was a fierce debate over nationalising life insurance. ${ }^{61}$ Conservative politicians and economists argued against a state monopoly because it ran counter to the principle of free competition, and because they did not trust the state to run an insurance institution efficiently. Those

\footnotetext{
59 Arps, Auf Sicheren Pfeilern, 81-98, 111.

60 Reeves, "State Insurance in New Zealand."

61 The following is based on Fanfani, "Insurance in Italy," 114-20.
} 
arguing for a state monopoly emphasised the growing proportion of Italian life insurance that was in the hands of foreign companies - about 41 per cent by 1912 and claimed that a state institution would help protect the savings and pensions of the wealthy and policyholders and investors from bankruptcies and from private company tariff rates. Despite the opposition, the Istituto Nazionale dell Assicurazioni (INA) was established in 1912. The law establishing INA allowed private companies to continue operating for up to 10 years, but required them to hand over to INA 40 per cent of every insurance they wrote. Few were prepared to do this and many companies left the market. The perceived problem of revenue flows to foreign insurers was greatly reduced after 1919 when national borders changed and the large Trieste companies, such as Generali and RAS, that had previously belonged to the Austrian empire, became Italian. ${ }^{62}$ INA's monopoly was abolished by Mussolini in 1923, but it continued operating and played an important role after 1945 in the finance of housing construction.

Between the 1920s and the 1950 s, full nationalisation, or alternatively some form of compulsion to insure or reinsure in a state-run institution, became popular with many regimes that aspired to economic autarky such as those in Chile, Uruguay, Turkey and Spain. In Argentina, the establishment of a public-private joint reinsurance venture, the Instituto Mixto Argentino de Reaseguros (IMAR) was part of a package of financial reforms introduced by the government of Juan Perón in 1946 that were designed to give the state greater control over the economy and to aid economic planning. Foreign insurers were required to reinsure with the IMAR 30 per cent of any business they wrote in Argentina. The IMAR was also tasked with

62 I am grateful to Giandomenico Piluso for making this point to me. 
examining all applications for licenses and testing these against market 'need', along the lines of the old police licensing systems in Europe. In 1952 the IMAR was replaced by the fully nationalised Instituto Nacional de Reaseguros (INDER), managed out of the Ministry of Finance. The effect of this two-stage process of nationalisation was dramatic. In 194644 per cent of reinsurance on Argentine risks was retroceded abroad. By 1958 that figure had fallen to below one per cent. ${ }^{63}$

Most of the above cases involved countries where native insurers were increasingly resorting to foreign companies for their reinsurance needs after foreign direct insurers had been squeezed out of the market by competition and discriminatory regulation and taxation. States such as Argentina then became concerned about the growing dependency of their countries on foreign supplies of reinsurance, though many recognised that there were limits to the domestic supply of reinsurance, which by its nature required an international distribution of risks. The nationalisation of life insurance in India also followed after the market share of foreign companies had been declining for some time. After independence, the new Indian government sought to reshape the economy in a socialist direction and in 1951 it introduced its first five-year plan. At the end of this plan life insurance was nationalised and a new state-owned Life Insurance Company of India (LIC) was set up. The finance minister, C.D. Deshmukh, explained that nationalisation would spread the life insurance habit into the rural population and provide policyholders with benefits that they could not expect from a privately-owned enterprise. The real objective, however, was to mobilise life insurance funds for social investment. Jitschin's analysis shows that loans and mortgages together accounted for 54 per cent of the LIC's investments by

63 Zappino, El Instituto Mixto. 
$1968 .{ }^{64}$ Before nationalisation, mortgages had never amounted to more than five per cent of the assets of private life insurance companies. The LIC even introduced an 'Own your own home' house-building scheme in 1964. Jitschin concludes that the LIC acted as a proxy for the Indian state in its investment strategy, supporting national political objectives.

Elsewhere, debates over nationalisation led to different outcomes. In Sweden in 1936 a nationalisation bill was only narrowly rejected by parliament. A year later the private insurance companies formed the Swedish Insurance Federation to lobby against the ongoing threat. In 1946, after ten years of discussion, a parliamentary commission finally recommended new laws that supported a private system with closer state regulation. The 'Swedish model' of insurance that emerged ended the long debate over nationalisation. The new laws greatly expanded the powers of the Swedish Insurance Inspectorate from the traditional monitoring of company solvency, which had been its primary function since 1886 , to assessing market demand when issuing licenses, monitoring the costs and premium rates of life insurance companies, requiring the separation of life insurance from other branches of insurance, requiring the representation of policyholders on the boards of both mutual and stock companies, and enforcing a 'mutuality' principle, namely that all life insurance companies must return profits to their policyholders, regardless of ownership structure. The private companies were not enthusiastic about the new regime, but they recognised that it was better for them than outright nationalisation. One effect of the legislation was to raise barriers to entry, which encouraged the larger companies to develop new low-cost products, to increase efficiency, and to expand via consolidation and mergers. ${ }^{65}$

64 Jitschin, "From Economic to Political Reality".

65 Larsson and Lönnborg, "Insurance Companies in Sweden". 


\section{Conclusions: the determinants and consequences of organisational form}

Throughout modern history the primary function of the state has been to protect its citizens and their property from hazards and threats, external and internal. It is clear that there has seldom been any time or place where the state has not been involved in the amelioration of risk, and therefore in some way or other, directly or indirectly, in the business of insurance. Public authorities have been gatekeepers, regulators and facilitators for private insurance markets, regulating the supply of insurance, monitoring sources of moral hazard, protecting domestic insurance companies by restricting the operations of foreign competitors and trying to ensure that companies met their obligations to policyholders and creditors. In its non-insurance regulatory role, the state has had the capacity to facilitate the growth of insurance by reducing risk and by diffusing data and technical knowledge about hazards. It has also been able to stimulate new markets, for example in personal and professional liability insurance, by regulating in the areas of consumer protection, environmental protection and health and safety.

Many states have also participated, directly or indirectly, in insurance markets, exploiting their power to compel citizens to pay premiums and taxes. What mainly determined the emergence of public insurance provision in the past? The changing nature of risk - a technology explanation - seems to have played, at most, a minor role. The problem of assessing and pricing new risks has largely been handled by the private sector - the explosion of new insurance products launched by Lloyd's underwriters from the 1880 s is one obvious example. ${ }^{66}$ During industrialisation in

\footnotetext{
66 Pearson, “Lloyd's of London”.
} 
nineteenth-century Europe, public fire insurance associations usually left more complex risks related to industrial property and contents to private companies. Another possible explanation - that public insurance emerged because of the inefficiency or failure of private markets - was often put forward by its advocates as a justification for state intervention, either indirectly through regulation or directly through the establishment of a state insurance institution. Yet there is only limited historical evidence that public insurance was any more efficient than private provision. There are examples to consider. Due to the efficiency of its loss adjustment procedures and its relatively low rate of contributions, the Salzburg buildings insurance association, established under Bavarian occupation in 1811, proved popular with local policyholders, and it survived the return of the Tirol region to Hapsburg rule in 1816 , despite the fact that the government in Vienna was already encouraging the formation of private companies for fire insurance ${ }^{67}$ Here and in other places in Europe, some public institutions were able to compete with private companies even without powers of compulsion or monopoly. This does not prove, however, that they were intrinsically more efficient. When gaps in the market were left by public providers, or when licensing restrictions or monopoly privileges were removed - as in marine insurance in Naples after 1811 or fire insurance in Prussia from the 1860s private insurers were usually quick to move in. Further research is required on the relative cost advantages and productivity of public and private forms of insurance before we can be sure how to evaluate the market efficiency explanation.

What comes across clearly from our investigation is the importance of political factors. The wave of public institutions for fire and marine insurance founded

67 Rohrbach, "Von den Anfängen,” 215-16, 221-3. 
across Europe in the eighteenth and nineteenth centuries reflected a growing interest on the part of governments to utilise their powers to improve the security of private property and incomes. This in turn was the product of changing economic, political and legal relations within states as the commercial and industrial bourgeoisie grew in wealth and influence. In the twentieth century some states began to nationalise or partly nationalise their insurance industries both for fiscal-monetary motives and also because of the logic of the politics of autarky and the desire to exercise control over major economic sectors such as financial services. Underlying the policies of various states was also often an ideological hostility to private enterprise, or at least a concern that for-profit insurance might be detrimental to public welfare. Moreover, as we have seen above, the varying alignments of narrow interest groups and broader political interests in different states could determine the fate of public insurance legislation and, for example, the shape of accident insurance in the US during the early twentieth century, or the social insurance systems developed in Sweden and the UK after 1945. In sum, it is probable that political cultures, and their associated bureaucratic and legal frameworks, created important path dependent effects, which determined and locked in, though not irreversibly, the organizational structure of markets and the distribution of insurance provision between the public and private sectors, and between different forms of private insurance - cooperatives, mutual associations, stock corporations, unincorporated stock companies, and syndicates of individual underwriters.

As noted in the introduction, the stronger version of path dependent theory posits that a sensitivity of choices to initial conditions leads to outcomes, most notably technologies, which are not only inefficient but which could have been 
avoided because more efficient alternatives were available. The argument made above for the importance of political cultures and state action in shaping persistent structures in national insurance markets makes no claims for the efficiency or inefficiency of the organizational forms thus locked in. Nevertheless, although it is not the principal object of this article, our historical survey does shed some light on the relative advantages and disadvantages of public insurance that are worth discussing.

There is no question that forms of state intervention have in many instances provided an enormous boost to the diffusion of insurance throughout the population. Mandatory state social insurance has delivered better cover against sickness, workplace injuries, unemployment and old age for growing numbers of people since the late nineteenth century. Many of these schemes, where they were not part of a universal integrated social security provision by the state, greatly expanded the market for private insurance companies. The result in many countries has been huge improvements in public welfare. State sickness insurance helped reduce mortality in Europe before 1914. Mandatory state schemes resulted in pensions for more workers in the UK from 1911, Sweden from 1913 and the US from 1935. The nationalisation of life insurance in India led to increased investment in public housing from the 1950s. Government treasuries were replenished by revenue from state insurance and reinsurance institutions in South America and New Zealand. Municipal fire fighting in eighteenth and nineteenth-century Europe was supported by revenue garnered from public buildings insurance associations.

The disadvantages of public insurance have been widely commented on. First, it has been argued that state-run insurance is inefficient. There is evidence to support this from across the period. Some public buildings associations, for example, 
struggled to accumulate sufficient funds to enable them to cope with the claims arising from large fires in their localities. This was the case in Sweden in the 1820s and in Hamburg after the great fire of 1842. The key problem was the high concentration of insured properties within an urban area, sometimes exacerbated by compulsory insurance, together with the lack of reinsurance facilities at the time. Direct participation in marine insurance by some European states during the eighteenth century had limited success. The heterogeneity of shipping risks was relatively costly for public (or indeed private) corporations to handle and it was difficult to find an actuarial basis upon which to price such risks. The low costs and information advantages developed by underwriters at Lloyd's of London and other centres of marine insurance usually gave them a competitive advantage over state corporations.

Second, it has been claimed that state insurance can distort the market, destroy privately provided alternatives, and redistribute funds from the broad base of taxpayers to special interest groups. ${ }^{68}$ Certainly public buildings insurance crowded out private fire insurance in markets such as Scandinavia and Germany over a long period of time. It also contributed to the fragmentation of these markets, though arguably it also increased consumer choice and kept prices down by reducing the power of the cartels formed by private companies. Third, it is said that state insurance can generate serious asymmetric information and adverse selection problems. History suggests there is validity in this argument. In early nineteenth-century Sweden, for example, the state fire insurance fund tended to select the safest risks, leaving the poorest timber-built property uninsured or for private underwriters to cover. Research

68 Wright, “Insuring America,” 259-60. 
shows that US farmers with access to state-subsidized insurance, price supports and disaster relief take on more financial and production risks than unsubsidized farmers do. The government flood insurance program in Louisiana induced construction in the southern part of the state, which weakened natural defences against flooding and increased the damage caused by hurricanes. Federal disaster relief and compensation has encouraged continued risk-taking and underinsurance by property owners in catastrophe-prone regions such as California and Florida. ${ }^{69}$ Similar arguments have been put forward for social security and national health insurance, that it discourages savings and private insurance provision, and perpetuates poverty and intergenerational wealth disparities by reducing the bequests of the less affluent to their children. A study of the expansion of the Medicaid programme in the US between 1987 and 1992, for example, concluded that this had reduced the take-up of employer-based private insurance and resulted in diminished coverage for workers' dependents. ${ }^{70}$

State insurance can leave a lasting footprint that is difficult to erase, even when governments resolve to liberalise and deregulate insurance markets. This is clearly shown in Kwon's study of Afghanistan, Bangladesh, Bhutan, Cambodia, Laos, Myanmar and Nepal. ${ }^{71}$ Between 1950 and 1975 they all nationalised insurance or established state-owned corporations and restricted the licensing of private companies shortly after independence. Since the early 1990s all have gradually privatised their insurance industries. Yet the legacy of nationalisation has proved tenacious. These markets continued until very recently to be dominated by state-owned institutions. Most continued to enforce compulsory cession requirements as a means of retaining

69 Wright, "Insuring America," 260; Froot, Financing of Catastrophe Risk.

$70 \quad$ Cutler and Gruber, "Public Insurance."

71 Kwon, "History of Insurance". 
reinsurance premiums in the country, which has increased the concentration of risk. Most failed to provide policyholder protection funds, continued to maintain premium rate tariffs, continued to lack effective solvency regulations, and continued to prohibit cross-border insurance transactions. In short, for insurance throughout history there has been, and continues to be, no escaping the state. 


\section{Bibliography of Works Cited}

Arps, Ludwig. Auf Sicheren Pfeilern: Deutsche Versicherungswirtschaft vor 1914, Göttingen: Vandenhoeck \& Ruprecht, 1965.

Arthur, W. Brian. Increasing Returns and Path Dependence in the Economy

(University of Michigan Press, 1994).

Bebel, August. Aus meinem Leben, Berlin: Dietz Verlag, 1964.

Bismarck, Otto von. Dokumente seines Lebens, Leipzig: Verlag Philipp Reclam, 1986.

Bleakley, Hoyt and Lin, Jeffrey. "History and the Sizes of Cities," American Economic Review 105 (2015): 558-63.

Borscheid, Peter. 275 Jahre Feuersozietäten in Westfalen: Vorprung durch Erfahrung, Münster, 1997.

Borscheid, Peter. "Vertrauensgewinn und Vertrauensverlust: Das Auslandsgeschäft der Deutschen Versicherungswirtschaft 1870-1945," Vierteljahrschrift für Sozial- und Wirtschaftsgeschichte 88 (2001): 311-45.

Borscheid, Peter. "History of the Insurance Industry in Germany," in Encuentro Internacional Sobre la Historia del Seguro, ed. Leonardo Caruana, Madrid:

Fundaçion Mapfre, 2010, 43-68.

Brewer, John. The Sinews of Power: War, Money and the English State, 1688-1783, Cambridge, MA: Harvard University Press, 1990.

Brown, Samuel. "On the Progress of Fire Insurance in Great Britain as Compared with Other Countries," Assurance Magazine 7 (1857-8). 
Büchner, F. "Die Entstehung der Hamburger Feuerkasse und ihre Entwicklung bis zur

Mitte des 19. Jahrhunderts," in Hamburger Feuerkasse, 300 Jahre Hamburger

Feuerkasse, Karlsruhe, 1976, 1-50.

Clark, Geoffrey. Betting on Lives: The Culture of Life Insurance in England,

1695-1775, Manchester: Manchester University Press, 1999.

Cutler, David M. and Gruber, Jonathan. "Does Public Insurance Crowd Out Private

Insurance," Quarterly Journal of Economics (1996): 391-430.

David, Paul A. "Clio and the Economics of QWERTY," American Economic Review 75 (1985): 332-7.

De Souza, Bruno Gabriel Witzel. "Immigration and the Path Dependence of Education: The Case of German-Speakers in São Paulo, Brazil (1840-1920),” Economic History Review 71 (2018): 506-39.

Driel, Hugo van and Devos, Greta. Path Dependence in Ports: The Persistence of Cooperative Forms," Business History Review 81 (2007): 681-708.

Engelberg, Ernst. Bismarck: Das Reich in der Mitte Europas, Berlin: Siedler Verlag, 1998.

Fanfani, Tommaso, "Private Insurance in Italy: A Sector for the Growth of the Nation," in Encuentro Internacional Sobre la Historia del Seguro, ed. Leonardo Caruana, Madrid: Fundaçion Mapfre, 2010, 97-140.

Fishback, Price V. and Kantor, Shawn Everett, “The Durable Experiment: State Insurance of Workmen's Compensation Risk in the Early Twentieth Century," Journal of Economic History 56 (1996): 809-36.

Froot, Kenneth A. ed., The Financing of Catastrophe Risk, Chicago and London: University of Chicago Press, 1999. 
Gesellschaft für Feuerversicherungsgeschichtliche Forschung e.v.. Das Deutsche Feuerversicherungswesen, 2 volumes, Hanover: Rechts, Staats und

Sozial-wissenschaftlicher Verlag, 1913.

Guinnane, Timothy W. and Streb, Jochen, "Incentives That (Could Have) Saved

Lives: Government Regulation of Accident Insurance Associations in Germany, 1884-1914," Journal of Economic History 75 (2015): 1196-1227.

Hannah, Leslie. Inventing Retirement: The Development of Occupational Pensions in Britain. Cambridge: Cambridge University Press, 1986.

Hansmann, Henry. "The Organisation of Insurance Companies: Mutual versus Stock," Journal of Law, Economics and Organisation 1 (1985):125-52.

Hansmann, Henry. The Ownership of Enterprise, Cambridge, MA: The Belknap Press, 1996.

Hennock, E. P. British Social Reform and German Precedents: The Case of Social Insurance, 1880-1914. Oxford: Clarendon, 1987.

Jitschin, Adrian, "From Economic to Political Reality: Forming a Nationalized Indian Life Assurance Market," in The Development of International Insurance, ed. Robin Pearson, London: Pickering and Chatto, 2010, 133-44.

Jones, W. J. "Elizabethan Marine Insurance: The Judicial Undergrowth," Business History 2 (1960): 53-66.

Kang, Z., “Assurances Moderne en Chine: Une Continuité Interrompue (1801-1949),” Risques no.31 (1997): 103-20.

Kepler, J. S. "The Operating Potential of London Marine Insurance in the 1570s:

Some Evidence from 'A Booke of Orders of Assurances within the Royall

Exchange'," Business History 17 (1975): 44-55. 
Kingston, Christopher, "Marine Insurance in Britain and America, 1720-1844: A

Comparative Institutional Analysis," Journal of Economic History 67 (2007): 379-409.

Kingston, Christopher, "Marine Insurance in Philadelphia during the Quasi-War with France, 1795-1801," Journal of Economic History 71 (2011): 162-84.

Koselleck, Reinhart. Preussen zwischen Reform und Revolution, Munich: DTV, 1989.

Kwon, W. Jean. "History of Insurance, Market Development and Regulation in Seven Least Developed Countries in Asia: Afghanistan, Bangladesh, Bhutan, Cambodia, Laos, Myanmar and Nepal," Asia-Pacific Journal of Risk and Insurance 5 (2010): $1-39$.

Larsson, Mats and Lönnborg, Mikael. "The History of Insurance Companies in Sweden, 1855-2005," in Encuentro Internacional Sobre la Historia del Seguro, ed. Leonardo Caruana, Madrid: Fundaçion Mapfre, 2010, 197-237.

Leonard, A.B. ed., Marine Insurance: Origins and Institutions, 1300-1850, Basingstoke: Palgrave Macmillan, 2016.

Liebowitz, S. J. and Margolis, Stephen E. "Path Dependence, Lock-in, and History", Journal of Law, Economics and Organization 11 (1995): 205-26.

Libecap, Gary D. “Institutional Path Dependence in Climate Adaptation: Conan’s 'Some Unsettled Problems of Irrigation'”, American Economic Review 101 (2011): 64-80.

Lönnborg, Mikael. Internationalisierung av Svenska Försäkringsbolag, Uppsala, 1999.

Lüdtke, Alf. Police and the State in Prussia 1815-50, Cambridge: Cambridge University Press, 1989. 
Macnicol, J. The Politics of Retirement in Britain, 1878-1948. Cambridge: Cambridge University Press, 1998.

Mesa-Lago, Carmelo. "History of Social Security in Latin America," in Encuentro Internacional Sobre la Historia del Seguro, ed. Leonardo Caruana, Madrid:

Fundaçion Mapfre, 2010, 309-47.

Mohun, Arwen P. Risk: Negotiating Safety in American Society, Baltimore: John Hopkins University Press, 2013.

Murray, John E. and Nilsson, Lars, “Accident Risk Compensation in Late Imperial Austria: Wage Differentials and Social Insurance," Explorations in Economic History 44 (2007): 568-87.

Pearson, Robin. "Who Pays for Pensions? Das Problem der Alterssicherung in Grossbritannien im Zwanzigsten Jahrhundert," Zeitschrift für

Unternehmensgeschichte 48 (2003): 48-57.

Pearson, Robin. Insuring the Industrial Revolution: Fire Insurance in Great Britain, 1700-1850, Aldershot: Ashgate, 2004.

Pearson, Robin. "Lloyd's of London," in History of World Trade since 1450, ed. John J. McCusker, 2 volumes, Farmington Hills, MI: Macmillan Reference, 2006, volume 2, 466-9.

Pearson, Robin and Yoneyama, Takau, eds., Corporate Forms and Organisational Choice in International Insurance, Oxford: Oxford University Press, 2015.

Raynes, Harold. A History of British Insurance, London: Sir Isaac Pitman \& Sons, 1948.

Reeves, W. P. “State Insurance in New Zealand,” North American Review 182 (1906): $62-73$. 
Rohrbach, Wolfgang. "Von den Anfängen bis zum Börsenkrach des Jahres 1873," in Versicherungsgeschichte Österreichs, ed. W. Rohrbach. 3 volumes. Vienna, 1988, volume $1,46-432$.

Roover, F. Edler de. "Early Examples of Marine Insurance," Journal of Economic History 5 (1945): 172-200.

Schulze, Winfried. "The Emergence and Consolidation of the 'Tax State'," in

Economic Systems and State Finance, ed. Richard Bonney. Oxford: Clarendon Press, $1995,261-79$.

Sirago, Maria and Avallone, Paola. "The Risk of the Sea: Maritime Insurance in Southern Italy from the $17^{\text {th }}$ to the $19^{\text {th }}$ Centuries," unpublished paper presented at the XV World Economic History Congress, Utrecht, 2009

Smith, B. D. and Stutzer, M. “A Theory of Mutual Formation and Moral Hazard with Evidence from the History of the Insurance Industry," The Review of Financial Studies 8 (1995): 545-77.

Stadlin, Christofer. “Actuarial Practice, Probabilistic Thinking and Actuarial Science in Private Casualty Insurance," in The Development of International Insurance, ed.

Robin Pearson, London: Pickering \& Chatto, 2010, 37-62.

Supple, Barry. The Royal Exchange Assurance: A History of British Insurance 1720-1970, Cambridge: Cambridge University Press, 1970.

Sydow, Jörg, Schreyögg, Georg and Koch, Jochen. “Organizational Path Dependence: Opening the Black Box," The Academy of Management Review 34 (2009): 689-709.

Tebeau, Mark. Eating Smoke: Fire in Urban America, 1800-1950, Baltimore: John Hopkins University Press, 2003. 
Thomasson, Melissa A. "From Sickness to Health: The Twentieth Century

Development of U.S. Health Insurance," Explorations in Economic History 39 (2002): 233-53.

Trebilcock, Clive. Phoenix Assurance and the Development of British Insurance, 2 volumes, Cambridge: Cambridge University Press, 1985, 1998.

Weaver, Carolyn L. "On the Lack of a Political Market for Compulsory Old Age Insurance Prior to the Great Depression: Insights from Economic Theories of Government," Explorations in Economic History 20 (1983): 294-328.

Westall, Oliver M. "The Invisible Hand Strikes Back: Motor Insurance and the Erosion of Organized Competition in General Insurance 1920-38," Business History 30 (1988): 423-50.

Winegarden, C. R. and Murray, John E. "The Contributions of Early Health Insurance Programs to Mortality Declines in Pre-World War I Europe: Evidence from Fixed-Effects Models," Explorations in Economic History 35 (1998): 431-46.

Wright, Robert E. "Insuring America: Market, Intermediated and Government Risk Management Since 1790," in Encuentro Internacional Sobre la Historia del Seguro, ed. Leonardo Caruana, Madrid: Fundaçion Mapfre, 2010, 239-98.

Zanjani, George. "Regulation, Capital, and the Evolution of Organisational Form in US Life Insurance," American Economic Review 97 (2007): 973-83.

Zappino, Jorge S. El Instituto Mixto Argentino de Reaseguros: La Formaçion de un Mercado Naçional de Seguros (1946-1952), Buenos Aires: Ediciones Cooperativas, 2007.

Zwierlein, Cornel. Der gezähmte Prometheus. Feuer und Sicherheit zwischen Früher Neuzeit und Moderne, Göttingen: Vandenhoeck \& Ruprecht, 2011. 


\section{Notes}

